\title{
POTENSI ANTIULSER SEDUHAN SERBUK BUAH MENGKUDU DAN KULIT DAUN LIDAH BUAYA TERHADAP GAMBARAN MAKROSKOPIK LAMBUNG
}

\author{
Robiyanto ${ }^{1}$, Marsiana Marsela ${ }^{2}$ \\ ${ }^{1,2}$ Program Studi Farmasi Fakultas Kedokteran Universitas Tanjungpura \\ Jalan Prof. Dr. H. Hadari Nawawi Pontianak 78124 \\ 1e-mail: robiyant@gmail.com
}

\begin{abstract}
Abstrak
Penelitian bertujuan untuk mengetahui pengaruh kombinasi serbuk buah mengkudu dan serbuk kulit daun lidah buaya sebagai antiulser terhadap tukak lambung tikus Wistar jantan yang diinduksi aspirin. Hewan uji dibagi menjadi kelompok kontrol normal/KN (akuades), kontrol negatif/K- (aspirin $90 \mathrm{~g} / \mathrm{kgBB}$ ), P1 (serbuk 0,27 $\mathrm{g} / \mathrm{kgBB}$ ), P2 (serbuk 0,54 g/kgBB) dan P3 (serbuk 0,81 g/kgBB). Induksi aspirin satu kali sehari selama 14 hari. Kombinasi serbuk diberikan pada hari ke-15 hingga ke-30. Tukak lambung diamati secara makroskopik pada hari ke-3 dan dinilai skor jumlah tukak dan skor diameter tukak serta dihitung indeks tukak lambung tiap kelompok. Data dianalisis dengan One-Way ANOVA. Hasil penelitian menunjukkan bahwa nilai indeks tukak P2 $(3,60)$ dan P3 $(2,80)$ berbeda signifikan dengan indeks tukak K- (7,50). Sehingga disimpulkan bahwa seduhan kombinasi serbuk buah mengkudu dan kulit daun lidah buaya kelompok P2 dan P3 memiliki potensi sebagai antiulser dengan nilai indeks tukak lambung lebih rendah dibandingkan dengan hasil kontrol negatif.
\end{abstract}

Kata Kunci: antiulser, aspirin, indeks tukak, lidah buaya, mengkudu.

\begin{abstract}
This research aimed at investigating the effect of combination of noni fruit and aloe vera leaf powder as an antiulser. This combination is given orally to male Wistar rat. The gastric ulcer in rat is induced by aspirin orally. Animals test were divided into five different groups: normal control (aquadest), negative control (aspirin 90 $\mathrm{g} / \mathrm{kgBW}), P 1(0.27 \mathrm{~g} / \mathrm{kgBW}), \quad P 2(0.54 \mathrm{~g} / \mathrm{kgBW})$ and $P 3(0.81 \mathrm{~g} / \mathrm{kgBW})$. Aspirin induction was given once in a day for 14 days for all groups. Powder combination for PI, P2, P3 were given from $15^{\text {th }}$ to $30^{\text {th }}$ day. Gastric ulcer was observed macroscopically on day 3 and scored amount of ulcer and ulcer diameter. Using these two scores, ulcer index was then calculated. Data obtained was analysed by using One-Way ANOVA statistic. The result of this research showed that the ulcer index score of P2 group (3.60) and P3 group (2.80) were significantly different from the score of gastric ulce in negative control (7.50). Based on this result, it is concluded that the combination of noni fruit and aloe vera leafe powder in P2 and $P 3$ groups have antiulcer effect with smaller gastric ulcer value index compared to the gastric ulcer value in negative control.
\end{abstract}

Keywords: antiulcer, aspirin, ulcer index, aloe vera, noni.

\section{PENDAHULUAN}

Tanaman mengkudu (Morinda citrifolia L.) dan lidah buaya (Aloe vera (L.)

Burm.f.) dapat digunakan sebagai bahan obat alternatif karena mengandung 
berbagai zat yang berfungsi sebagai penghambat berbagai penyakit. Jumlah antioksidan terbanyak pada makanan bersumber dari buah dan sayur, salah satunya adalah mengkudu (Oguntibeju, 2010). Buah mengkudu mengandung alkaloid xeronin yang dapat meningkatkan kekebalan tubuh dan meregenerasi selsel yang rusak. Berdasarkan penelitian Hendriani (2017), pemberian kombinasi ekstrak etanol buah mengkudu dan rimpang jahe gajah hasil pengamatan secara makroskopik menunjukkan tidak ada kelainan organ juga tidak ditemukan adanya tukak di lambung hewan uji. Secara garis besar buah mengkudu dapat mencegah dan mengobati berbagai gangguan kesehatan dan penyakit (Latief, 2012).

Lidah buaya telah dibudidayakan secara luas di Kalimantan Barat, khususnya Pontianak pada lahan lebih dari 25.000 ha (Winarti, 2005). Lidah buaya dimanfaatkan sebagai bahan pangan, kosmetik maupun sebagai bahan obat (Edy, 2011). Lidah buaya memiliki kandungan aktif antara lain lupeol, asam salisilat, fenol, sulfur, magnesium, zinc, vitamin A, vitamin C, dan vitamin E (Dewi, 2010). Berdasarkan penelitian Harsa (2015), pemberian ekstrak lidah buaya berpengaruh terhadap penyembuhan mukosa lambung tikus wistar putih jantan yang diberi etanol $80 \%$.

Pemanfaatan buah mengkudu dan kulit lidah buaya dapat menjadi suatu produk pangan fungsional. Kulit daun lidah buaya dapat dikeringkan dan dapat diseduh seperti teh (Septiani, 2015). Hasil akhir olahan mengkudu juga beragam mulai dari minuman kesehatan atau krim untuk obat hingga kosmetik. Produk pangan fungsional yang digunakan dalam penelitian berupa minuman kesehatan dan biasanya dikonsumsi secara rutin setiap hari dan dalam jangka waktu yang lama untuk mendapatkan daya tahan tubuh dan menjaga kesehatan.

Lambung adalah salah satu organ saluran pencernaan yang berfungsi sebagai penampung makanan dan mengatur makanan yang masuk ke duodenum (Walangitan, 2014). Ulkus peptikum atau tukak lambung adalah kondisi terjadinya kerusakan mukosa lambung yang diikuti oleh proses inflamasi (Katzung, 1998). Hal tersebut disebabkan beberapa hal, diantaranya yaitu infeksi Helicobacter pylori, penggunaan Obat Anti Inflamasi Non Steroid (OAINS) jangka panjang ataupun disebabkan akibat stress (Gilman, 2012). 
Ulkus peptikum paling sering disebabkan oleh penggunaan OAINS (Lastri, 2003). Efek gastrointestinal OAINS meliputi erosi lambung, pembentukan tukak lambung dan perforasi, perdarahan saluran gastrointestinal atas dan inflamasi, serta perubahan permeabilitas usus halus bagian bawah (Lastri, 2003). Salah satu OAINS ialah aspirin yang merupakan obat analgesik, anti piretik, dan anti inflamasi. Pemberian aspirin dapat menimbulkan perubahan kualitatif mukus lambung sehingga menyebabkan jaringan lambung mengalami kerusakan (Nanlohy, 2013).

Berdasarkan permasalahan tersebut, maka penelitian bertujuan untuk mengetahui pengaruh kombinasi serbuk buah mengkudu dan serbuk kulit daun lidah buaya sebagai antiulser terhadap tukak lambung tikus Wistar jantanyang diinduksi aspirin.

\section{METODE}

\section{Bahan}

Bahan yang digunakan dalam penelitian adalah kombinasi serbuk buah mengkudu dan kulit lidah buaya yang terdapat di pasaran, aspirin, amoniak, akuades, asam asetat anhidrat $\left(\mathrm{CH}_{3} \mathrm{COOH}\right)$, asam klorida $(\mathrm{HCl})$, asam sulfat $\left(\mathrm{H}_{2} \mathrm{SO}_{4}\right)$, diklorometan $\left(\mathrm{CH}_{2} \mathrm{Cl}_{2}\right)$, etil asetat, $\mathrm{FeCl}_{3}$, gelatin, kloroform, magnesium (Mg) serbuk, metanol 70\%, n-heksana, natrium-carboxymethyl cellulose (CMC $\mathrm{Na}$ ), natrium klorida $(\mathrm{NaCl})$, pereaksi Dragendorff, pereaksi Mayer, pereaksi Lieberman-Burchadt, dan pereaksi Wagner. Hewan uji yang digunakan dalam penelitian adalah tikus (Rattus novergicus) galur Wistar, umur 2 bulan dengan bobot rata-rata 200 gram tanpa cacat fisik.

\footnotetext{
Alat

Alat yang digunakan dalam penelitian adalah timbangan analitik, alat-alat gelas, ball filler, hot plate, peralatan bedah, kantung plastik hitam, kertas saring, alumunium foil, spuit injeksi, sonde p.o, dan kandang hewan uji.
} 


\section{Prosedur Penelitian}

\section{Skrining fitokimia}

Skrining fitokimia merupakan tahap awal untuk mendeteksi secara kualitatif golongan senyawa metabolit dari serbuk kombinasi buah mengkudu dan kulit daun lidah buaya dengan menggunakan berbagai pereaksi. Adapun uji skrining fitokimia yang dilakukan meliputi pemeriksaan alkaloid, flavonoid, tanin, saponin, fenolik, steroid-terpenoid serta dengan pengujian Kromatografi Lapis Tipis (KLT).

\section{Uji alkaloid}

Serbuk kering $500 \mathrm{mg}$ dilarutkan dalam kloroform $2 \mathrm{~mL}$, ditambahkan $5 \mathrm{~mL}$ amoniak. Kemudian larutan disaring ke dalam tabung reaksi dan filtrat ditambahkan 10 tetes $\mathrm{H}_{2} \mathrm{SO}_{4} 2 \mathrm{~N}$ dan dikocok sampai terbentuk dua lapisan. Dipipet lapisan atas (asam) dan dimasukkan ke dalam 3 buah tabung reaksi. Kemudian masing-masing tabung tersebut ditambahkan beberapa tetes pereaksi Mayer, Dragendorf, dan Wagner. Adanya senyawa alkaloid ditandai dengan terbentuknya endapan putih dengan peraksi Mayer, dengan pereaksi Wagner memberikan endapan berwarna coklat dan pereaksi Dragendorff memberikan endapan berwarna jingga (Marlinda, 2012).

\section{Uji flavonoid}

Serbuk $200 \mathrm{mg}$ dilarutkan dengan $5 \mathrm{~mL}$ etanol dan dipanaskan selama 5 menit di dalam tabung reaksi. Selanjutnya ditambahkan beberapa tetes $\mathrm{HCl}$ pekat. Kemudian ditambahkan pita Mg. Hasil positif ditunjukkan dengan timbulnya warna merah tua selama 3 menit (Marlinda, 2012).

\section{Uji sterol dan triterpenoid}

Serbuk ditambahkan asam asetat glasial sampai semua sampel terendam, dibiarkan selama 15 menit kemudian 6 tetes dipindahkan kedalam tabung reaksi dan ditambahkan 2-3 tetes asam sulfat pekat. Adanya senyawa golongan triterpenoid akan ditandai dengan timbulnya warna merah, jingga atau unggu, sedangkan adanya senyawa golongan steroid ditandai dengan munculnya warna biru (Marlinda, 2012). 


\section{Uji tannin}

Serbuk ditambahkan etanol sampai terendam semuanya. Kemudian ditambahkan 2-3 tetes larutan $\mathrm{FeCl}_{3}$. Hasil positif ditunjukkan dengan terbentuknya warna hitam kebiruan atau hijau (Marlinda, 2012).

\section{Uji saponin}

Serbuk dimasukkan ke dalam tabung reaksi dan dilarutkan dengan akuades hingga seluruh sampel terendam, dididihkan selama 2-3 menit, dan selanjutnya didinginkan, kemudian dengan kuat. Hasil positif jika pada sampel terbentuk buih yang stabil selama tidak kurang dari 1 menit, setinggi $1 \mathrm{~cm}$ sampai $10 \mathrm{~cm}$ (Kristanti, 2008).

\section{Uji fenol}

Serbuk dilarutkan dalam air panas, kemudian ditambahkan $\mathrm{FeCl}_{3} \quad 1 \%$ sebanyak 2-3 tetes. Hasil positif ditunjukkan dengan perubahan warna sampel menjadi warna hijau, biru atau ungu kehitaman (Atmoko, 2009).

\section{Pemberian Seduhan Kombinasi Serbuk Buah Mengkudu dan Kulit Lidah Buaya}

Pemberian seduhan yang dimaksud dalam penelitian adalah pemberian seduhan yang dibuat dengan cara melarutkan serbuk buah mengkudu dengan akuades yang telah dipanaskan pada hot plate kemudian disaring menggunakan kertas saring. Volume seduhan yang diberikan peroral adalah $3 \mathrm{ml}$ untuk satu kali pemberian. Aspirin diberikan satu kali sehari dengan dosis $90 \mathrm{mg} / \mathrm{kgBB}$ pada pagi hari 3 jam sebelum pemberian pakan standar selama 14 hari untuk kelompok Kontrol Negatif, P1, P2, dan P3.

Seduhan diberikan setelah hewan uji diinduksi aspirin yaitu pada hari ke-15 selama 16 hari untuk kelompok P1, P2, dan P3 sesuai dengan dosis yang telah ditentukan. Perlakuan diberikan peroral menggunakan spuit dengan volume yang disamakanratakan yaitu $3 \mathrm{ml}$. Selama perlakuan, tikus diberi makan dan minum ad libitum. Perlakuan dilakukan dengan waktu selama 30 hari.

\section{Penetapan Derajat Kerusakan Lambung}

Secara makroskopik derajat kerusakan lambung dinilai dengan menggunakan sistem skoring (Gusnindar, et al., 2009). Pengujian efek 
ulcernogenic dilakukan pengambilan gambar lambung yang telah mengalami tukak dan dihitung jumlah tukak serta pengukuran diameter tukak, kemudian dibandingkan dengan kelompok kontrol. Tingkat keparahan tukak dinyatakan sebagai indeks tukak, yang dihitung menggunakan persamaan 1 (Gusnindar, et al., 2009):

$$
\text { Indeks Tukak }=\mathrm{A}+\mathrm{B}
$$

Keterangan: $\mathrm{A}=$ rata - rata jumlah skor tukak dan $\mathrm{B}=$ rata - rata skor diameter tukak

Tabel 1 Skoring Keparahan Tukak (Gusnindar et al., 2009)

\begin{tabular}{lll}
\hline \multicolumn{1}{c}{ Jumlah Tukak } & Skor & \multicolumn{1}{c}{ Kondisi/Diameter Tukak } \\
\hline Lambung Normal & $\leftarrow 1 \rightarrow$ & Lambung Normal \\
Bintik Berdarah & $\leftarrow 2 \rightarrow$ Bintik Berdarah \\
Jumlah Tukak 1-3 Buah & $\leftarrow 3 \rightarrow$ Diameter Tukak 0,5-1,5 mm \\
Jumlah Tukak 4-6 Buah & $\leftarrow 4 \rightarrow$ Diameter Tukak 1,6-4,0 mm \\
Jumlah Tukak 7-9 Buah & $\leftarrow 5 \rightarrow$ Diameter Tukak $>4,0 \mathrm{~mm}$ \\
Jumlah Tukak > 9 Buah & $\leftarrow 6 \rightarrow$ Perforasi \\
\hline
\end{tabular}

\section{HASIL DAN PEMBAHASAN}

\section{Skrining Fitokimia}

Hasil skrining fitokimia seduhan kombinasi serbuk buah mengkudu dan kulit lidah buaya dapat dilihat pada Tabel 2.

Tabel 2 Tabel Hasil Skrining Fitokimia Seduhan Kombinasi Serbuk Buah Mengkudu dan Kulit Daun Lidah Buaya

\begin{tabular}{llc}
\hline Metabolit Sekunder & \multicolumn{1}{c}{ Pereaksi } & Keterangan \\
\hline Alkaloid & Mayer & $(+)$ \\
& Dragendorff & $(+)$ \\
& Wagner & $(+)$ \\
Flavonoid & Pita Mg dan & $(+)$ \\
& HCl Pekat & \\
Steroid-Triterpenoid & Lieberman- & $(+)$ \\
& Burchad & Steroid \\
Saponin & Akuades & $(+)$ \\
Tanin & $\mathrm{FeCl}_{3}$ & $(+)$ \\
\hline Keterangan: (+) mengandung golongan senyawa
\end{tabular}




\section{Pengujian Antiulser}

Penelitian aktivitas antiulser bertujuan untuk melihat aktivitas seduhan kombinasi serbuk buah mengkudu dan kulit daun lidah buaya terhadap gambaran makroskopik kerusakan lambung setelah diinduksi aspirin. Induksi tukak dalam penelitian ini menggunakan aspirin $90 \mathrm{mg} / \mathrm{grBB}$ selama 14 hari.

Seduhan kombinasi serbuk buah mengkudu dan kulit daun lidah buaya menggunakan variasi dosis seduhan kombinasi serbuk buah mengkudu dan kulit daun lidah buaya menggunakan dosis pemberian 1 kali sehari, pemberian 2 kali sehari, dan pemberian 3 kali sehari pada hari ke 15-30. Pengamatan dilakukan dengan skoring jumlah ulser, kondisi/diameter ulser, dan nilai indeks ulser.

Hasil uji normalitas dan homogenitas varian menunjukkan bahwa data tidak terdistribusi secara normal sehingga dilakukan uji non parametrik. Hasil uji Kruskal Wallis menunjukkan adanya perbedaan bermakna pada jumlah ulser dan dimeter/kondisi ulser dengan $\mathrm{P}<0,05$. Hal tersebut mengindikasi bahwa terdapat pengaruh perlakuan terhadap jumlah ulser dan dimeter/kondisi ulser.

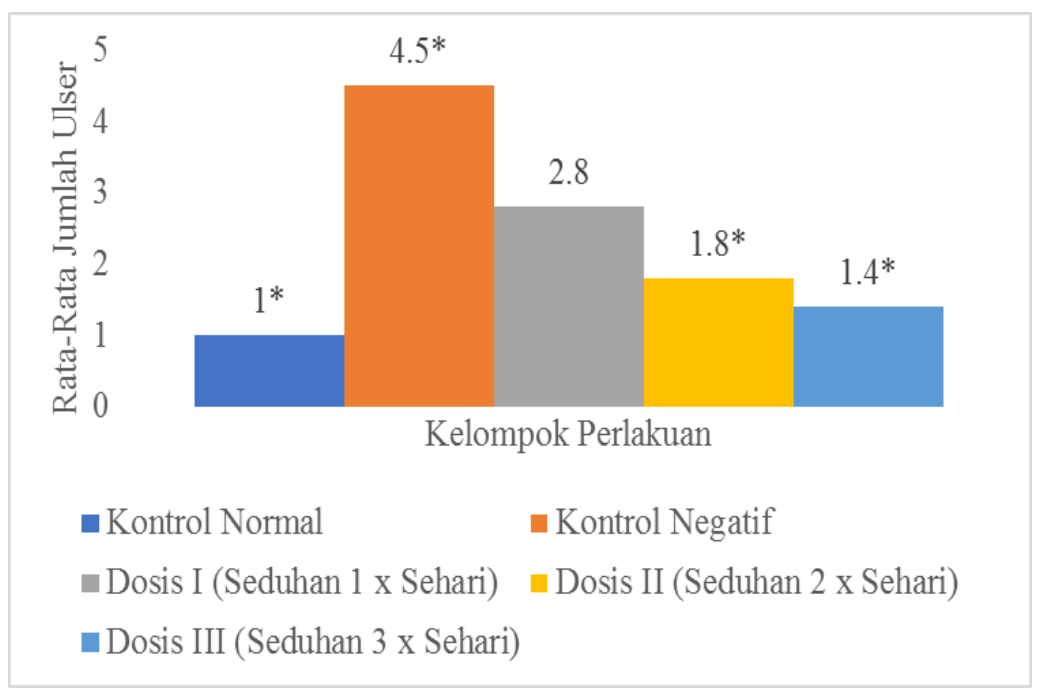

Gambar 1 Diagram Hasil Skor Nilai Rata-Rata Jumlah Ulser

Keterangan: $(*)=$ berbeda signifikan terhadap kontrol negatif

Berdasarkan nilai rata-rata jumlah ulser pada Gambar 1, terlihat bahwa kelompok kontrol negatif memiliki skor yang paling tinggi yaitu 4,5. Kelompok kontrol negatif berbeda signifikan terhadap kontrol normal. Sedangkan pada 
kelompok dosis II dan dosis III nilai rata-rata jumlah ulser lebih rendah $(1,8)$ dan $(1,4)$ berbeda signifikan terhadap kelompok kontrol negatif. Hal tersebut berarti kelompok dosis II dan dosis III memiliki potensi sebagai antiulser. Semakin besar dosis atau frekuensi pemberian seduhan nilai rata-rata jumlah ulser semakin kecil.

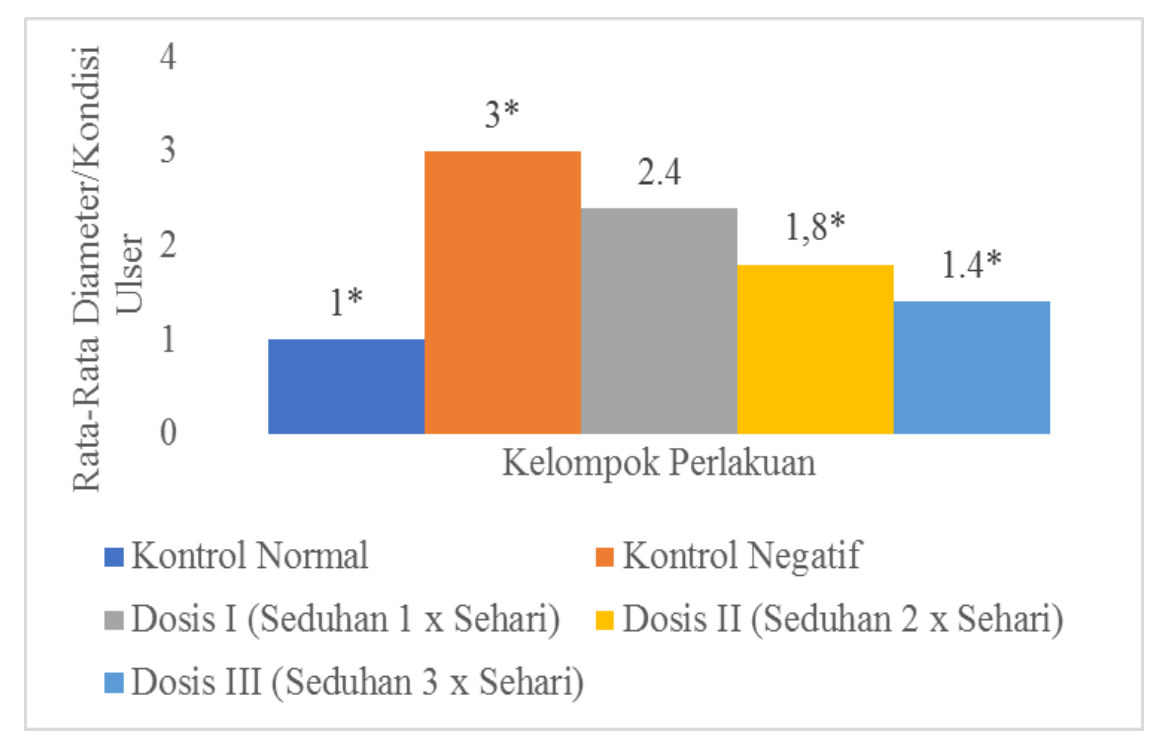

Gambar 2 Diagram Hasil Skor Nilai Rata-Rata Diameter/Kondisi Ulser

Keterangan: $(*)=$ berbeda signifikan terhadap kontrol negatif

Berdasarkan nilai rata-rata diameter/kondisi ulser pada Gambar 2, terlihat bahwa kelompok kontrol negatif memiliki skor yang paling tinggi yaitu 3 . Kelompok kontrol negatif berbeda signifikan terhadap kontrol normal. Sedangkan pada kelompok dosis II dan dosis III nilai diameter/kondisi ulser lebih rendah $(1,8)$ dan $(1,4)$ berbeda signifikan terhadap kelompok kontrol negatif. Hal tersebut berarti kelompok dosis II dan dosis III memiliki potensi sebagai antiulser. Semakin besar dosis atau semakin sering pemberian seduhan nilai rata-rata diameter/kondisi ulser semakin kecil. Dengan didapatkan nilai rata-rata jumlah ulser dan nilai rata-rata diameter/kondisi ulser maka dapat digunakan untuk menentukan nilai indeks ulser. Hasil perhitungan indeks ulser dari Jumlah tukak dan kondisi/diameter tukak dihitung berdasarkan metode skoring.

Berdasarkan hasil perhitungan indeks ulser terlihat bahwa kelompok kontrol negatif memiliki skor yang paling tinggi yaitu 7,50. Sedangkan pada kelompok dosis II dan dosis III nilai rata-rata jumlah ulser lebih rendah $(3,60)$ dan $(2,80)$ 
berbeda signifikan terhadap kelompok kontrol negatif. Hal tersebut berarti kelompok dosis II dan dosis III memiliki potensi sebagai antiulser. Maka semakin kecil nilai indeks ulser aktivitas antiulser semakin besar.

Tabel 3 Hasil Perhitungan Indeks Ulser

\begin{tabular}{|c|c|c|c|}
\hline Kelompok & $\begin{array}{c}\text { Skor Jumlah } \\
\text { Ulser }^{(57)} \\
(\bar{X} \pm \mathrm{SD})\end{array}$ & $\begin{array}{c}\text { Skor } \\
\text { Kondisi/Diameter } \\
\text { Ulser }^{(57)} \\
(\bar{X} \pm S D)\end{array}$ & $\begin{array}{l}\text { Indeks Ulser }^{(57)} \\
\text { (skor jumlah ulser } \\
\text { + skor kondisi/ } \\
\text { diameter ulser) }\end{array}$ \\
\hline Kontrol Normal & $1,0 \pm 0,00$ & $1,0 \pm 0,00$ & $2,00 *$ \\
\hline Kontrol Negatif & $4,5 \pm 0,57$ & $3,0 \pm 0,81$ & $7,50 *$ \\
\hline Dosis I & $2,8 \pm 0,44$ & $2,4 \pm 0,54$ & 5,20 \\
\hline Dosis II & $1,8 \pm 0,44$ & $1,8 \pm 0,44$ & $3,60^{*}$ \\
\hline Dosis III & $1,4 \pm 0,54$ & $1,4 \pm 0,54$ & $2,80 *$ \\
\hline
\end{tabular}

Keterangan: $(*)$ : berbeda signifikan terhadap kontrol negatif

Hasil pengamatan terhadap jumlah ulser pada lambung dengan uji MannWhitney menunjukkan bahwa jumlah ulser pada kelompok dosis I, II, dan III berbeda dengan signifikan dengan kelompok kontrol negatif yang artinya bahwa pada dosis I, II, dan III memiliki potensi sebagai antiulser. Pada kelompok dosis I berbeda signifikan dengan dosis II dan dosis III yang artinya bahwa pada dosis I belum memberikan efek maksimal dari dosis II dan dosis III terhadap lambung tikus yang rusak setelah diinduksi aspirin. Kelompok dosis II dan dosis III nilai jumlah ulser tidak berbeda secara bermakna $(\mathrm{P}>0,05)$. Semakin tinggi dosis seduhan, maka skor jumlah ulser semakin kecil.

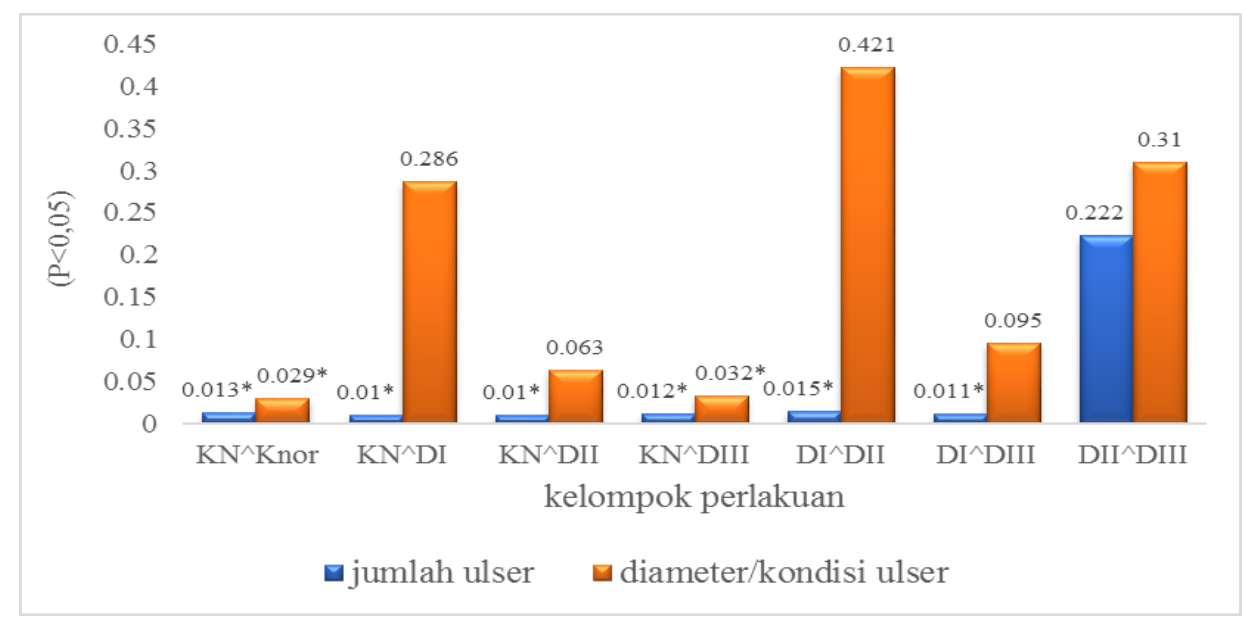

Gambar 3 Diagram Hasil Pengamatan Uji Mann-Whitney 
Keterangan: $(*)=$ berbeda signifikan $(\mathrm{P}<0,05) ; \mathrm{KN}=$ Kontrol Negatif; Knor $=$ Kelompok Normal; DI = Dosis I; DII = Dosis II; DIII = Dosis III

Pengamatan terhadap diameter/kondisi ulser pada lambung dengan uji Mann-Whitney menunjukkan bahwa diameter/kondisi ulser pada kelompok dosis III berbeda signifikan dengan kelompok kontrol negatif. Hal tersebut berarti bahwa dosis III memiliki potensi sebagai antiulser. Kelompok dosis I terhadap dosis II dan dosis III nilai diameter/kondisi ulser berbeda signifikan $(\mathrm{P}<0,050)$. Sedangkan dosis II terhadap dosis III nilai diameter/kondisi ulser tidak berbeda signifikan $(\mathrm{P}<0,050)$. Hal tersebut menunjukkan bahwa dosis I memiliki potensi sebagai antiulser namun kurang maksimal seperti dosis II dan dosis III. Semakin tinggi dosis seduhan yang diberikan, maka skor diameter/kondisi ulser semakin kecil.

Pengamatan makroskopik lambung tikus pada kelompok normal tidak memperlihatkan adanya kerusakan menunjukkan gambaran mukosa lambung normal atau tidak mengalami perubahan nilai indeks tukak 2,00 dapat dilihat pada Gambar 4a. Pada kelompok negatif yaitu kelompok yang diinduksi asam asetil salisilat dosis $90 \mathrm{mg} / \mathrm{grBB}$ selama 14 hari menunjukkan adanya kerusakan lambung dengan nilai indeks tukak 7,50 dapat dilihat pada Gambar 4b. Hal tersebut sesuai dengan efek asam asetil salisilat yang dapat mengiritasi lambung dengan menghambat enzim siklooksigenase (COX1) sehingga sintesis protein berkurang. Prostaglandin dapat melindungi mukosa lambung dengan merangsang sekresi mucus dan bikarbonat serta meningkatkan aliran arah mukosa. Adanya penghambatan prostaglandin mengakibatkan kerusakan mukosa lambung.

Kelompok yang diberi seduhan kombinasi serbuk buah mengkudu dan kulit daun lidah buaya kelompok P1 dengan dosis 0,27 gram menunjukkan adanya proteksi erhadap kerusakan lambung terlihat adanya perubahan pada mukosa lambung namun efek yang diberikan potensinya masih kurang ditunjukkan dengan nilai indeks tukak 5,20 kemudian masih terdapat bintik berdarah dan luka (tukak) pada mukosa lambung dapat dilihat pada Gambar 4c. Kelompok P2 dosis 0,54 gram menunjukkan adanya proteksi terhadap kerusakan lambung terlihat dengan nilai indeks tukak 3,60 dan adanya perubahan pada mukosa lambung 
dengan berkurangnya jumlah bintik berdarah dan tidak terdapat luka pada mukosa lambung dapat dilihat pada Gambar 4d. Kelompok P3 dosis 0,81 gram menunjukkan adanya proteksi terhadap kerusakan lambung terlihat dengan nilai indeks tukak 2,80 dan adanya perubahan pada mukosa lambung yang rata-rata tidak berbeda dengan kelompok kontrol normal Gambar 4e.

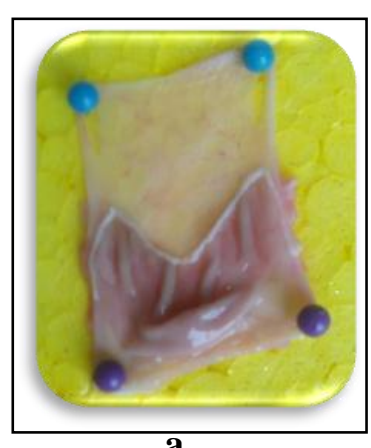

$\mathbf{a}$

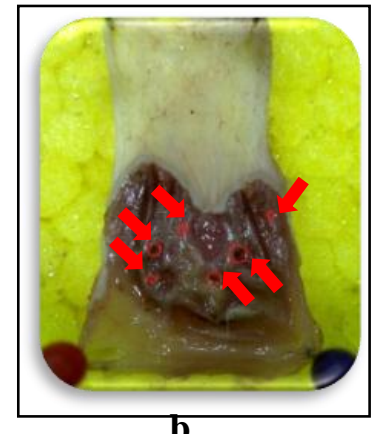

b

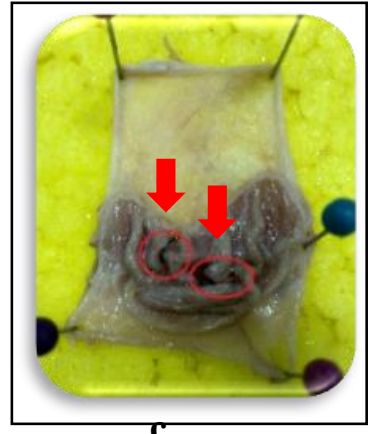

c

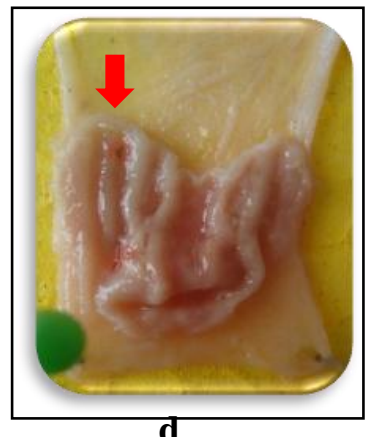

d

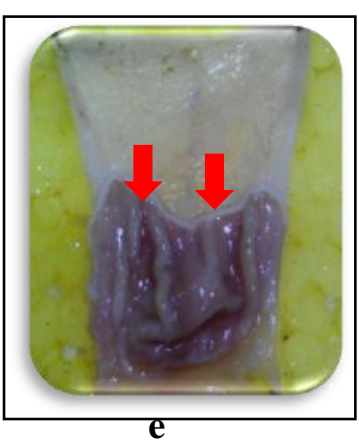

Gambar 4 Gambaran Makroskopik Tukak Lambung Tikus Wistar Jantan (a) Knor; (b) KN; (c) DI; (d) DII; dan (e) DIII

Pemberian seduhan pada kelompok P2 yaitu pemberian peroral 2 kali sehari dan kelompok P3 yaitu pemberian peroral 3 kali sehari memiliki potensi menurunkan kerusakan lambung. Hal tersebut akibat kerja dari kandungan zat aktif yang terkandung dari seduhan tersebut. Kandungan flavonoid pada buah mengkudu yang berfungsi sebagai antioksidan terhadap radikal bebas (Febrianti, 2013). Senyawa antioksidan adalah senyawa yang dapat menunda, menghambat atau mencegah oksidasi lipid atau molekul dengan inisiasi menghambat reaksi oksidatif berantai (Rohman, 2016). Buah mengkudu menghasilkan sederetan antioksidan diantaranya: scopoletin, flavonoid, vitamin $\mathrm{C}$, dan nitrit oksidan (Bijanti, 2008). 
Tanaman mengkudu diklaim memiliki aktivitas antiulser (Wang, 2002). Keterkaitan antara tukak lambung yaitu flavonoid meningkatkan kandungan prostaglandin mukosa, menurunkan sekrsi histamin dari sel mast oleh penghambatan histidine derkaboksilse dan sebagai radikal scavengers (Borrelli, 2002). Beberapa flavonoid juga meningkatkan prostaglandin mukosa dan mukus mukosa lambung sehingga mndorong pembentukan mukosa lambung serta menunjukan efek sitoprotektif (Windari, 2017).

Senyawa alkaloid pada buah mengkudu mengurangi sekresi asam lambung, meningkatkan sekresi mukus dan alkali, serta memperbaiki aliran darah mukosa lambung sehingga membantu penyembuhan dan pencegahan tukak lambung terhadap agen/faktor iritan (Falcao, et al., 2008). Kandungan tanin diketahui memiliki aktivitas antiulser. Mekanisme tanin sebagai antiulser adalah dengan mengurangi sekresi asam lambung (Kumar, 2011). Tanin memengaruhi integritas dari membran mukosa dan membentuk lapisan film pelindung untuk mencegah penyerapan zat racun (Bennet, 2008).

\section{SIMPULAN}

Pemberian seduhan kombinasi serbuk buah mengkudu (Morinda citrifolia L.) dan serbuk kulit lidah buaya (Aloe vera (L.) Burm.f.) peroral memiliki pengaruh terhadap gambaran makroskopik lambung tikus Wistar. Terdapat perbedaan signifikan indeks ulser lambung tikus Wistar antara kelompok perlakuan yaitu kelompok PII dan PIII dengan kelompok kontrol negatif setelah diberikan seduhan kombinasi serbuk buah mengkudu (Morinda citrifolia L.) dan kulit lidah buaya (Aloe vera (L.) Burm.f.) setelah diinduksi dengan aspirin. Dosis seduhan yang memberikan efek maksimal sebagai antiulser yaitu $810 \mathrm{mg} / \mathrm{kgBB}$.

\section{DAFTAR PUSTAKA}

Atmoko, T. 2009, Uji toksisitas dan skrining fitokimia ekstrak tumbuhan sumber pakan orangutan terhadap larva Artemia salina L. Jurnal Penelitian Hutan dan Konversi Alam: Balai Penelitian Teknologi Pembenihan Samboja, 4(1) : 37-45. 
Bennet, P. N. 2008. Clinical Pharmacology. Ed 10 ${ }^{\text {th }}$. Churchill Livingstone: London.

Bijanti, R. 2008. Potensi sari buah mengkudu (Morinda citrifolia) terhadap Kualtas Karkas, Kadar Vitamin C, dan Kadar Malonedia Idehide (MDA) dalam Darah Ayam Pedaging. Media Kedokteran Hewan, 24(1).

Borrelli, F. 2002. Review articel: The Plant Kingdom as a Source O Anti-Ulcer Remidies. Phytotherapy Research, 14: 581-591.

Dewi, K. 2010. The Comparison Effect of Aloe vera L., Psidium guajava L., Curcuma domestica val to Colitis Ulcerative Mice Models Histopatology. Jurnal Medika Planta, 1(2).

Edy, H. 2011. Pengeringan Lidah Buaya (Aloe vera) Menggunakan Oven Gelombang Mikro (Microwave Oven). Jurnal Keteknikan Pertanian, 25(2).

Falcao, P. I., et al. 2008. Diabetes Worsen Diastolic Left Ventricular Dysduction in Aortic Stenosis Throught Altered Myocardial Structure and Caryomyocytes Stiffnes. Circulation.

Gilman, G. 2012. Dasar Farmakologi Terapi. Edisi 10. Jakarta: EGC.

Harsa, S. M. I. 2015. Pengaruh Pemberian Ekstrak Lidah Buaya (Aloe vera) terhadap Penyembuhan Mukosa Lambung Tikus Putih Jantan (Rattus novergicus) yang Diberi Etanol 80\%. e-Journal. Surabaya: Universitas Wijaya Kusuma Surabaya.

Hendriani, R. 2017. Uji Toksisitas Subkronis Kombinasi Ekstrak Etanol Buah Mengkudu (Morinda citrifolia Linn.) dan Rimpang Jahe Gajah (Zingiber officinale Rosc.) pada Tikus Wistar. Tesis. Bandung: Universitas Padjadjaran.

Katzung, B. G. 1998. Farmakologi Dasar dan Terapi. Jakarta: EGC.

Kristanti, A. N. 2008. Buku Ajar Fitokimia. Surabaya: Unair Press.

Kumar, V. 2011. Buku Ajar Patologi. Edisi 7. EGC: Jakarta.

Lastri, P. 2003. Obat-Obat Anti Inflamasi Non Steroid. Jakarta: Cermin Dunia Kedokteran.

Latief, H. A. 2012. Obat Tradisional. Jakarta: EGC. 
Marlinda, M. 2012. Analisis Senyawa Metabolit Sekunder dan Uji Toksisitas Ekstrak Etanol Biji Buah Alpukat (Persea Americana Mill.). Jurnal FMIPA Unsrat, 1(1) : 24-28.

Nanlohy, J. V. 2013. Gambaran Histopatologi Lambung Tikus Wistar yang Diberikan Buah Papaya Sebelum Induksi Aspirin. Jurnal e-Biomedik, 1(2).

Oguntibeju, O. O. 2010. Possible Role of Red Palm Oil Supplementation in Reducing Oxidative Stress in HIV/AIDS and TB Patients: A Review. Journal of Medical Plant Research, 4(3): 188-196.

Rohman, A. 2006. Aktivitas Antioksidan, Kandungan Buah Mengkudu Fenolik Total dan Kandungan Flavonoid Total Ekstrak Etil Asetat Buah Mengkudu serta Fraksi-Fraksinya. Majalah Farmasi Indonesia, 17(3) : 136-142.

Septiani. 2015. Pengaruh Umur Daun Lidah Buaya (Aloe vera barbadensis Miller) dan Perlakuan Blanching terhadap Karakteristik Inderawi Permen Jelly Daun Lidah Buaya. Skripsi. Semarang: Universitas Negeri Semarang.

Walangitan, J. 2014. Efek Pemberian Ekstrak Kayu Manis (Cinamomun burmannii) terhadap Gambaran Histopatologi Lambung Tikus Wistar yang Diberi Aspirin. Jurnal e-Biomedik, 2(2).

Wang, M. Y. 2002. Morinda citrifolia (Noni): a Literature Review and Recent Advances in Noni Research. Acta Pharmacologica Sinica, 23(12): 11271141.

Winarti, C. 2005. Peluang Tanaman Rempah dan Obat Sebagai Sumber Pangan Fungsional. Jurnal Litbang Pertanian, 24(2).

Windari, T. 2017. Peranan Ekstrak Bawang Dayak (Eleutherine palmifolia) sebagai Agen Anti Tukak Lambung (Peptic Ulcer) pada Tikus Wistar (Rattus novergicus) Jantan yang Diinduksi Etanol. Jurnal Pangan dan Agroindustri, 5(1) : 61-70. 